\title{
Lapsuuden ja aikuisuuden sosioekonomisten olosuhteiden yhteydet aikuisiän painonkehitykseen
}

Jokaisella meistä on omakohtaisia kokemuksia kehonpainon muutoksista ja painonhallinnasta - ehkä myös niihin liittyvistä haasteista. Toisilla meistä painoa on kertynyt suhteellisen tasaisesti aina lapsuudesta asti, toisilla taas painonmuutokset ovat ehkä muistuttaneet enemmän pitkäkestoista vuoristorataa. Monilla meistä on varmasti myös mielipiteitä ja ajatuksia siitä, mistä nämä painonmuutokset ovat johtuneet. Ehkä osataan tunnistaa elintavoissa, kuten ruokavaliossa, liikunnassa ja unessa, tapahtuneita muutoksia. Jo$\mathrm{ku}$ voi kertoa stressaavista elämänvaiheista painonmuutosten taustalla, toinen taas saattaa viitata perimäänsä ja perhetaustaansa. Yksilön painonkehityksen ja painonnousun taustalta voidaan tosiaankin löytää lukuisia sisäisiä ja ulkoisia tekijöitä $(1,2)$. Vaikka toki yksinkertaisesti energiatasapaino - eli se, miten energiaa kulutetaan suhteessa energian saantiin - on yksilön kehonpainon ja sen muutosten ytimessä, ovat siihen vaikuttavat mekanismit ja syy-seuraussuhteet hyvinkin monimutkaiset.

Vaikka jokaisella yksilöllä on oma painohistoriansa ja kehityspolkunsa painonsa kanssa, voidaan yhteiskuntatasolla löytää tiettyjä keskeisiä trendejä siitä, miten väestön paino keskimäärin kehittyy iän ja ajan saatossa. Globaalissa mittakaavassa ylipaino ja lihavuus ovat yleistyneet viimeisten vuosikymmenten aikana kaikilla maapallon mantereilla (3). Suomi ei ole tässä kehityksessä poikkeus. Vuonna 2017 tehdyn Finterveystutkimuksen mukaan joka neljäs suomalainen aikuinen luokiteltiin painoindeksin mukaan lihavaksi, ja lähes kaksi kolmasosaa naisista ja kolme neljäsosaa miehistä ylipainoiseksi (4). Naisilla lihavuus yleistyy iän mukaan, kun taas miehillä se on yleisintä keski-iässä. Niin sanottu normaalipainoisuus, eli painoindeksin ollessa 18,5-24,9 $\mathrm{kg} / \mathrm{m}^{2}$, ei siis enää olekaan niin normaalia väestössämme. Yhä enemmän onkin alettu puhua normaalipainon sijaan terveestä painosta. Tällä viitataan siihen, että painoindeksin ollessa näissä rajoissa, riski moniin sairauksiin, kuten sydän- ja verisuonitauteihin, useisiin syöpiin ja tyypin 2 diabetekseen, on keskimäärin pienempi kuin painoindeksin ollessa näiden rajojen ulkopuolella (5-7). Fyysisen terveyden lisäksi lihavuus vaikuttaa myös ihmisen psyykkiseen ja sosiaaliseen hyvinvointiin $(8,9)$. Kun tähän lisätään vielä lihavuudesta aiheutuvat taloudelliset seuraukset (10), voidaan olla yhtä mieltä siitä, että nykyiset trendit ylipainon ja lihavuuden yleistymisessä haastavat enenevissä määrin niin yksilöitä kuin yhteiskuntaakin.

Nämä globaalit trendit eivät kosketa kuitenkaan tasaisesti eri väestöryhmiä. Jo 1960-luvulla yhdysvaltalaistutkimus havaitsi, että vanhemman matala sosioekonominen asema lisäsi jälkeläisen riskiä aikuisiän lihavuudelle (11). Myöhemmät tutkimukset aina tähän päivään asti ovat vahvistaneet lihavuuden sosioekonomisten erojen olemassaolon. Sosioekonomisella asemalla viitataan siis sekä hyvinvoinnin aineellisiin edellytyksiin, kuten rahaan ja omaisuuteen, että myös niiden hankkimiseen tarvittaviin voimavaroihin ja edellytyksiin, kuten tietoihin, taitoihin ja arvoihin (12). Sosioekonomista asemaa mitataan usein koulutuksen, ammattiaseman ja tulojen kautta. Vauraissa länsimaissa, joihin Suomikin kuuluu, alempi sosioekonominen asema on yhteydessä suurempaan painoon, ja tämä voidaan nähdä niin lapsilla kuin aikuisillakin (13, 14). Erityisen vahvoja nämä yhteydet ovat naisilla. Kehittyvissä maissa yhteyden suunta taas on pääosin päinvastainen (13). Suomessa painon sosioekonomiset erot ovat pysyneet sitkeästi tasaisen suurina vuosikymmenten ajan - samaan aikaan kun väestön keskimääräinen paino on jatkanut nousuaan $(4,15)$. Esimerkiksi vuoden 2017 FinTerveys-tutkimuksen mukaan joka kolmas perusasteen koulutuksen saaneista aikuisista luokiteltiin lihavaksi, kun taas korkea-asteen 
koulutuksen saaneista tämä osuus oli alle neljännes (4).

Herää tietysti kysymys, mistä sosioekonomiset erot lihavuudessa johtuvat. Selityksiä voidaan löytää useita. Esimerkiksi taloudellinen epävarmuus voi johtaa siihen, ettei yksilöllä ole riittäviä resursseja ostaa terveellistä ja monipuolista ruokaa tai harrastaa itselle mieleisiä liikunta-aktiviteetteja. Sosiaalinen ympäristö, kuten perhe-, kaveri- ja työyhteisöt, eivät välttämättä tue parhaalla tavalla terveellisten elintapojen ylläpitämisessä sosioekonomisesti huono-osaisemmissa ryhmissä. Kyvyt arvioida ja soveltaa terveellisiä elintapoja ja painonhallintakeinoja voivat olla heikommat vähemmän koulutusta saaneilla. Painonhallintaa tukevien palveluiden saatavuus voi myös olla haastavampaa. Lisäksi kaikki nämä tekijät saattavat aiheuttaa ylimääräistä stressiä yksilölle, mikä edelleen vaikeuttaa painonhallintaa. Koska elintapojen tiedetään usein siirtyvän sukupolvelta toiselle (16), kasautuvat nämä edellä mainitut lihavuuden riskitekijät myös jälkeläisille, mikä puolestaan antaa heille heikommat lähtökohdat terveellisiin elintapoihin ja painonhallintaan.

Sosioekonomiset erot ylipainossa ja lihavuudessa eivät toki ole irrallaan muista elintapa- ja terveystekijöistä: alemman sosioekonomisen aseman tiedetään altistavan niin heikommalle työja toimintakyvylle, sairastavuudelle kuin haitallisemmalle terveyskäyttäytymisellekin (17-20). Erityisen lihavuudesta tekee kuitenkin se, että lihavuus itsessään näyttäisi kasvattavan terveyseroja verrattain paljon (21). Sekä kansallinen että kansainvälinen tutkimusnäyttö on osoittanut, että lihavuus vaikeuttaa erityisesti naisten kouluttautumista ja työuralla etenemistä $(9,22)$. Lihavuuden stigma eli sosiaalinen häpeäleima elää yhteiskunnassamme vahvana, ja lihavuuteen saatetaan yhä perusteettomasti yhdistää negatiivisia ominaisuuksia kuten laiskuutta, taitamattomuutta tai vähempiälyisyyttä. Ylipainoiset voivatkin pahimmillaan joutua kohtaamaan läpi elämän kiusaamista ja syrjintää painonsa vuoksi. Naisiin ja tyttöihin kohdistuvat ulkonäköpaineet ovat erityisen suuret, mikä osaltaan vaikuttaa siihen, että sosioekonomiset erot painossa ovat selkeämmin nähtävissä naisilla kuin miehillä (23). Jotta näitä eroja voitaisiin kaventaa, täytyisi siis voida vaikuttaa myös niihin sosiokulttuurisiin arvoihin, käsityksiin ja rakenteisiin, jotka mahdol- listavat ylipainoisten syrjinnän eri yhteisöissä, kuten kouluissa, harrastuksissa ja työelämässä.

Vaikka tieteellinen tutkimusnäyttö lihavuuden sosioekonomisista eroista on vahvaa, riittää yhä tutkittavaa. Tämän hetkinen tutkimusnäyttö perustuu yhä pitkälle poikkileikkausasetelmiin, jolloin niin sosioekonomisissa olosuhteissa, painossa kuin niiden vuorovaikutuksessakin tapahtuvat muutokset jäävät helposti havaitsematta. Lisäksi tutkimusasetelmat, joissa pystyttäisiin selvittämään lapsuuden olosuhteiden yhteyksiä painonkehitykseen aina myöhäisaikuisuuteen asti, ovat harvassa. Voisiko esimerkiksi omalla kouluttautumisella ehkäistä epäterveellistä painonnousua riippumatta siitä, millaiset lähtökohdat on lapsuudessa saanut? Entä jatkuuko lihavuuden sosioekonomisen eriarvoisuuden kasautuminen vielä keski-iän jälkeenkin? Vaikka julkisessa keskustelussa ollaan usein kiinnostuneita lähinnä yksilön painossa tapahtuneista lyhyen aikavälin muutoksista ja laihdutuksesta, on painossa tapahtuvat pitkän aikavälin muutokset lopulta ratkaisevia niin yksilön kuin yhteisöjenkin terveyden ja hyvinvoinnin näkökulmasta. Siksi onkin tärkeää tunnistaa pitkän aikavälin kehityspolkuja painossa sekä ymmärtää, mitkä tekijät ovat näiden kehityspolkujen taustalla.

Tässä väitöstukimuksessa selvitin, miten lapsuuden ja aikuisuuden sosiaaliset ja taloudelliset olosuhteetovatyhteydessäaikuisiänpainon-taitäsmällisemmin sanottuna painoindeksin - kehityspolkuihin. Aineistona käytin Helsinki Health Study -kohorttitutkimusta, jossa alkuperäinen tutkimusjoukko muodostui Helsingin kaupungin lähes 9000:sta 40-60-vuotiaasta työntekijästä vuosina 2000-2002 (24). Seurantaa on tähän mennessä jatkettu vuoteen 2017 asti, ja tutkimukseni aineisto koostuikin kaikista neljästä saatavilla olevasta kyselytutkimuksesta. Tutkin työntekijöiden painoindeksin kehityspolkuja ikävuosien 25 ja 77 välillä, hyödyntäen sekä henkilö- että muuttujalähtöisiä tilastollisia menetelmiä. Ensimmäisessä osatyössä (25) keskityin lapsuuden sosioekonomisiin olosuhteisiin ja lapsuudessa tapahtuneisiin vastoinkäymisiin, kuten kiusatuksi joutumiseen ja perheen sosiaalisiin ja taloudellisiin vaikeuksiin. Toisessa osatyössä (26) tutkin aikuisiällä tapahtuneita muutoksia kotitalouden tuloissa ja koetuissa taloudellisissa vaikeuksissa eri painoindeksin kehityspolkuryhmien sisällä. Kolmannessa osatyössä (27) puolestaan keski- 
tyin sosiaaliseen liikkuvuuteen, jolla tässä tutkimuksessa tarkoitettiin koulutuksellista siirtymää tutkittavan vanhemman koulutustason ja oman koulutustason välillä.

Väitöskirjani tutkimustulokset osoittivat, että epäsuotuisammat sosioekonomiset olosuhteet sekä lapsuudessa että aikuisuudessa olivat yhteydessä jyrkempään aikuisiän painonnousuun. Naisilla erot olivat selkeämmin havaittavissa kuin miehillä. Lisäksi tulokseni osoittivat, että yhteydet olivat sitä selkeämpiä, mitä suurempaa painon kertyminen oli aikuisiässä. Esimerkiksi osatyö 1 näytti, että vanhemman matala koulutus oli yhteydessä ylipainon kehittymiseen, mutta vielä vahvemmin merkittävän ja vaikean lihavuuden kehittymiseen (25). Naisilla myös kiusatuksi joutuminen ja vastoinkäymisten kasautuminen lapsuudessa lisäsivät todennäköisyyttä kuulua lihavuuden kehityspolkuryhmiin.

Osatyö 2 paljasti, että kotitalouden tuloissa näkyvät erot painoindeksissä kasvoivat 17 vuoden seurannan aikana (26). Lisäksi henkilöt, joilla painonnousu oli suurinta, kärsivät todennäköisemmin taloudellisesta epävarmuudesta koko seurannan ajan. Heikommat taloudelliset olosuhteet olivat jatkuvasti sitä yleisempiä henkilöillä, joilla paino nousi eniten seurannan aikana. Sosioekonominen gradientti painonmuutoksissa oli selkeästi havaittavissa: siirtyminen heikommista taloudellisista olosuhteista kohti parempia olossuhteita esiintyi yhtäaikaisesti siirryttäessä terveellisestä painonkehityksestä kohti lihavuuden kehittymistä.

Osatyössä 3 havaitsin, että jatkuvasti matala sosioekonominen asema lapsuudesta aikuisuuteen oli yhteydessä suurimpaan painoindeksiin ikävuosien 40 ja 77 välillä (27). Miehillä lisäksi alaspäin suuntautunut sosiaalinen liikkuvuus oli yhteydessä korkeampaan painoindeksiin. Tarkasteltaessa ylisukupolvista sosiaalista liikkuvuutta ja painoindeksiä kahdessa eri syntymäkohortissa voitiin nähdä, että nuoremmassa syntymäkohortissa tutkittavan oma koulutus oli painoindeksin eroissa keskeisemmässä roolissa kuin tutkittavan vanhemman koulutus. Tulokset saattavat vihjailla siitä, että nuoremmissa ikäluokissa sosioekonomiset erot painonkehityksessä voisivat kasvaa iän mukaan enemmän kuin vanhemmissa ikäluokissa. Elintavat eivät näyttäneet selittävän täysin yhteyksiä sosiaalisen liikkuvuuden ja painonkehityksen välillä.
Yhteenvetona voidaan todeta, että tutkimustulokseni vahvistavat aiempaa poikkileikkauksellista tutkimusnäyttöä siitä, että sekä lapsuuden että aikuisuuden epäsuotuisat sosioekonomiset olosuhteet ovat yhteydessä suurempaan painoindeksiin aikuisiällä, naisilla hieman selkeämmin kuin miehillä. Tutkimustulokseni toivat uutta näkökulmaa siitä, miten nämä yhteydet näyttäytyvät pitkän aikavälin seuranta-asetelmassa. Esimerkiksi lapsuuden olosuhteilla saattaa olla hyvinkin pitkäaikaisia vaikutuksia painonkehitykseen, aina myöhäisaikuisuuteen asti. Jo lapsuudessa alkava sosiaalisten ja taloudellisten riskitekijöiden kasautuminen voi altistaa epäterveelliselle painonnousulle, mikä taas edelleen kiihdyttää vuorovaikutusta epäsuotuisten olossuhteiden ja painonnousun välillä. Vaikka tutkimuksessani ei pystytty todentamaan syy-seuraussuhteita, on todennäköistä, että sosiaalisten ja taloudellisten riskitekijöiden sekä painonnousun suhde on nimenomaa vuorovaikutteista. Esimerkiksi naisilla esille tullut yhteys lapsuuden kiusatuksi joutumisen ja aikuisiän lihavuuden kehityspolkujen välillä voi kertoa sekä lihavuuteen liittyvästä kiusaamisesta lapsuudessa ja sen seurauksista myöhempään painonnousuun, tai yleisesti kiusaamisen sosiaalisista vaikutuksista painonnousuun. Lisäksi aikuisiässä jatkunut taloudellinen eriarvoisuus painoindeksin kehityspoluissa antaa viitteitä taloudellisten tekijöiden ja painon vuorovaikutuksesta.

Mitä siis voitaisiin tehdä, jotta epäsuotuisten sosioekonomisten olosuhteiden ja painonnousun vuorovaikutus voitaisiin katkaista? Kysymykseen ei ole varmasti yhtä oikeaa ja kaikenkattavaa vastausta. On kuitenkin selvää, että lihavuuden ja sen eriarvoisuuden ennaltaehkäisy on ennen kaikkea yhteiskunnallinen haaste. Globaalit trendit lihavuuden yleistymisessä ovat pitkälti seurausta ympäristössämme tapahtuneista muutoksista ja megatrendeistä, kuten ruokaympäristön muuttumisesta energiapitoista syömistä tukevaksi (28). Yksilöt eivät ole yhtäläisessä asemassa ja yhtäläisin resurssein kohtaamassa näitä ympäristössä tapahtuvia muutoksia. Lihavuuden ennaltaehkäisy ja painonhallintaan liittyvä keskustelu on kuitenkin pitkään keskittynyt siihen, miten $y k s i l o ̈$ voi hallita elintapojaan. Omasta mummolastani löytämässä vuoden 1971 Valittujen Palojen lääkärikirjassa (29) - joka tuohon aikaan oli varsin yleinen näky suomalaisten kirjahyllyillä - mainitaan esimerkiksi näin: 
"Jos ibmisellä on taipumus lihavuuteen, hän saa taistella koko ikänsä sitä vastaan. Sellaisen ibmisen on kerta kaikkiaan päätettävä pitää puolensa - ja hänen on tehtävä päätöksensä niin vankoin perustein, että hän todella jaksaa pitää painonsa kurissa. Liian monet ihmiset kerran laihduttuaan päästävät itsensä undelleen lihomaan. He eivät ole tehneet päätöstään kyllin vahvoin perustein. Juuri siksi on tärkeä tietää lihavunden terveydelle aiheuttamat vakavat vaarat."

Vaikka ymmärrys lihavuudesta ja sen syistä on toki lisääntynyt paljon noista ajoista, riittää arkipäivän asenteissa ja käytänteissä yhä paljon parantamisen varaa. Kuten nykyinen tutkimusnäyttö - mukaan lukien tämä väitöskirja - antaa ymmärtää, yksilölle kohdistettu terveysvalistus ruokavalio- ja liikuntaneuvoineen on riittämätöntä, jos ei tunnisteta niitä aineellisia ja henkisiä resursseja ja sosiaalisia ympäristöjä, joiden keskellä yksilöt päivittäin elävät. Tästä taas hyvänä esimerkkinä on 15.3.2021 Helsingin Sanomissa julkaistu mielipidekirjoitus nimimerkillä Laihduttaja (30). Kirjoittaja kuvailee tekstissään sitä, miten hän on kamppaillut laihdutuksen, painonsa ja siitä aiheutuvan häpeän kanssa lapsuudesta saakka ja saanut painonhallintaan avukseen "hienoja kaloritaulukoita ja paperimonisteita lautasmalleista". Lopuksi kirjoittaja esittää huolensa painonhallintaryhmien lakkauttamisista koronaviruspandemian aikana ja kysyy: "Miten ja mistä saa apua koko elämänsä laibduttanut pienituloinen nainen?”.

Koronaviruspandemia on muistuttanut meitä hyvin siitä, miten ympäristömme haasteet tuntuvat erityisesti jo valmiiksi heikommassa asemassa olevien yksilöiden ja ihmisryhmien keskuudessa. Lisäksi vallitseva pandemia ja sen pitkän aikavälin seuraukset eivät tule todennäköisesti ainakaan helpottamaan ylipainon ja lihavuuden sosioekonomisen eriarvoisuuden kaventamista lähivuosina. Jos nykyiset trendit ylipainon ja lihavuuden yleistymisessä jatkavat kasvuaan, on vaarana lihavuuden sosioekonomisten erojen kasvu, ja siten myös terveyden eriarvoisuuden lisääntyminen. Terveyden eriarvoisuuden vähentäminen on ollut jo vuosikymmeniä keskeinen tavoite terveyspolitiikassa, mutta erot ovat tästä huolimatta säilyneet sitkeästi (31). Koska lihavuus on yksi keskeinen terveyseroja kasvattava tekijä, tulisi lihavuuden ennaltaehkäisyyn suh- tautua vakavasti kaikilla yhteiskunnan eri alueilla ja tasoilla. Ainoastaan sosiaali- ja terveydenhuollon panos ei riitä, vaan tarvitaan tiivistä yhteistyötä niin koulutuksen, työelämän, talous- ja sosiaalipolitiikan, median kuin elintarviketeollisuudenkin kanssa. Yhteiseksi kysymykseksi ja haasteeksi jää, miten jokainen meistä voi olla edistämässä sellaista fyysistä, psyykkistä ja sosiaalista ympäristöä, jossa jokaisella yksilöllä on aidosti mahdollisuus elää hyvinvoivasti sekä tehdä terveydelle suotuisia valintoja.

\section{LÄHTEET:}

(1) Dahl AK, Reynolds CA, Fall T, Magnusson PKE, ym. Multifactorial analysis of changes in body mass index across the adult life course - A study with 65 years of follow-up. Int J Obes 2014;38:1133-1141. doi: 10.1038/ijo.2013.204

(2) Silventoinen K, Jelenkovic A, Sund R, ym. Differences in genetic and environmental variation in adult BMI by sex, age, time period, and region: an individual-based pooled analysis of 40 twin cohorts. Am J Clin Nutr 2017;106:457466. doi: 10.3945/ajcn.117.153643

(3) NCD Risk Factor Collaboration (NCD-RisC). Trends in adult body-mass index in 200 countries from 1975 to 2014: a pooled analysis of 1698 population-based measurement studies with $19 \cdot 2$ million participants. Lancet 2016;387:1377-1396. doi: 10.1016/S0140-6736(16)30054-X

(4) Lundqvist A, Männistö S, Jousilahti P, ym. Lihavuus. Kirjassa: Koponen P, Borodulin K, Lundqvist A, ym. (toim.), Terveys, toimintakyky ja hyvinvointi Suomessa: FinTerveys 2017 tutkimus. Helsinki: Terveyden ja hyvinvoinnin laitos (THL); Raportti 4/2018, 45-49. http://urn.fi/URN:ISBN:978-952-343-105-8

(5) Kivimäki M, Kuosma E, Ferrie JE, ym. Overweight, obesity, and risk of cardiometabolic multimorbidity: pooled analysis of individuallevel data for 120813 adults from 16 cohort studies from the USA and Europe. Lancet Public Health 2017;2:e277-285. doi: 10.1016/S2468-2667(17)30074-9

(6) Guh DP, Zhang W, Bansback N, ym. The incidence of co-morbidities related to obesity and overweight: A systematic review and metaanalysis. BMC Public Health 2009;9:88. doi: 10.1186/1471-2458-9-88

(7) Park D, Lee JH, Han S. Underweight: another risk factor for cardiovascular disease?: A cross-sectional 2013 Behavioral Risk Factor Surveillance System (BRFSS) study of 491,773 individuals in the USA. Medicine (Baltimore) 2017;96:e8769.

doi: 10.1097/MD.0000000000008769

(8) Luppino FS, de Wit LM, Bouvy PF, ym. Overweight, obesity, and depression: a systematic review and meta-analysis of longitudinal studies. 
Arch Gen Psychiatry 2010;67:220-229.

doi: 10.1001/archgenpsychiatry.2010.2

(9) Puhl RM, Heuer CA. The Stigma of Obesity: A Review and Update. Obesity (Silver Spring) 2009;17:941-964. doi: 10.1038/oby.2008.636

(10) Dee A, Kearns K, O’Neill C, ym. The direct and indirect costs of both overweight and obesity: a systematic review. BMC Res Notes 2014;7:242. doi: 10.1186/1756-0500-7-242

(11) Goldblatt PB, Moore ME, Stunkard AJ. Social factors in obesity. JAMA 1965;192:1039-1044. doi: 10.1001/jama.1965.03080250017004

(12) Galobardes B, Shaw M, Lawlor DA, ym. Indicators of socioeconomic position (part 1). J Epidemiol Community Health 2006;60:7-12. doi: 10.1136/jech.2004.023531

(13) McLaren L. Socioeconomic status and obesity. Epidemiol Rev 2017;29:29-48. doi: 10.1093/epirev/mxm001

(14) Barriuso L, Miqueleiz E, Albaladejo R, ym. Socioeconomic position and childhood-adolescent weight status in rich countries: a systematic review, 1990-2013. BMC Pediatr 2015;15:129. doi: 10.1186/s12887-015-0443-3

(15) Prättälä R, Sippola R, Lahti-Koski M, ym. Twenty-five year trends in body mass index by education and income in Finland. BMC Public Health 2012;12:936. doi: 10.1186/1471-2458$12-936$

(16) Umberson D, Crosnoe R, Reczek C. Social relationships and health behavior across the life course. Annu Rev Sociol 2010;36:139-157. doi: 10.1146/annurev-soc-070308-120011

(17) Aittomäki A, Lahelma E, Roos E. Work conditions and socioeconomic inequalities in work ability. Scand J Work Environ Health 2003;29(2):159-165. doi: 10.5271/sjweh.718

(18) Laaksonen E, Martikainen P, Head J, ym. Associations of multiple socio-economic circumstances with physical functioning among Finnish and British employees. Eur J Public Health 2009;19(1):38-45. doi: 10.1093/eurpub/ckn123

(19) Kivimäki M, Batty GD, Pentti J, ym. Association between socioeconomic status and the development of mental and physical health conditions in adulthood: a multi-cohort study. Lancet Public Health 2020;5(3):e140-e149. doi: 10.1016/S2468-2667(19)30248-8

(20) Pampel FC, Krueger PM, Denney JT. Socioeconomic Disparities in Health Behaviors. Annu Rev Sociol 2010;36:349-370. doi: 10.1146/annurev.soc.012809.102529

(21) Hoffmann R, Eikemo TA, Kulhánová I, ym. Obesity and the potential reduction of social inequalities in mortality: evidence from 21 European populations. Eur J Public Health 2015;25:849-856. doi: 10.1093/eurpub/ckv090

(22) Härkönen J, Räsänen P, Näsi M. Obesity, unemployment, and earnings. Nord J Work Life Stud 2011;1:23-38.

doi: 10.19154/njwls.v1i2.2343
(23) Pudrovska T, Reither EN, Logan ES, ym. Gender and reinforcing associations between socioeconomic disadvantage and body mass over the life course. J Health Soc Behav 2014;55(3):283-301. doi: $10.1177 / 0022146514544525$

(24) Lahelma E, Aittomäki A, Laaksonen M, ym. Cohort Profile: The Helsinki Health Study. Int J Epidemiol 2013 42, 722-730. doi: $10.1093 /$ ije/dys039

(25) Salmela J, Mauramo E, Lallukka T, ym. Associations between childhood disadvantage and adult body mass index trajectories: A follow-up study among midlife Finnish municipal employees. Obes Facts 2019;12(5):564-574. doi: 10.1159/000502237

(26) Salmela J, Lallukka T, Mauramo E, ym. Body mass index trajectory-specific changes in economic circumstances: A person-oriented approach among midlife and ageing Finns. Int J Environ Res Public Health 2020;17(10):3668. doi: 10.3390/ijerph17103668

(27) Salmela J, Lallukka T, Kanerva N, ym. Intergenerational social mobility and body mass index trajectories: A follow-up study from Finland. SSM Popul Health 2020;13:100723. doi: 10.1016/j.ssmph.2020.100723

(28) Hruby A, Hu FB. The epidemiology of obesity: A big picture. PharmacoEconomics 2015;33:673689. doi: 10.1007/s40273-014-0243-x

(29) Karjalainen A, Tola JS, Tola S, ym. Ihminen, luonnon mestariteos. Oy Valitut Palat - Reader's Digest Ab. Helsinki: Kustannus Oy Otava, Sanomapaino; 1971, 391-392.

(30) Helsingin Sanomat 2021. Mitä saan apua painonhallintaan koronaviruspandemian aikana? Lukijan mielipide. Helsingin Sanomat 15.3.2021. Luettu 15.3.2021. https://www.hs.fi/mielipide/art2000007859780.html

(31) Jokela S, Kilpeläinen K, Parikka S, ym. (toim.). Terveyden eriarvoisuus Suomessa: ehdotus seurantajärjestelmän kehittämiseen. Helsinki: Terveyden ja hyvinvoinnin laitos (THL); Raportti 5/2021. http://urn.fi/ URN:ISBN:978-952-343-656-5

\section{Jatta Salmela}

FT, ETM, TtM, tutkijatobtori

Helsingin yliopisto

Elintarviketieteiden maisteri ja terveystieteiden maisteri Jatta Salmelan väitöskirja "Socioeconomic circumstances from childhood to adulthood and body mass index trajectories: a Finnish occupational cohort study" tarkastettiin Helsingin yliopiston lääketieteellisessä tiedekunnassa 8.10.2021. Vastaväittäjänä toimi dosentti Marjaana Labti-Koski Suomen Sydänliitosta ja kustoksena prosessori Tea Lallukka Helsingin yliopistosta. 